\title{
SELECTED ASPECTS OF IRAN'S HYDROLOGICAL SECURITY
}

The demand for water in Iran is growing dynamically in agriculture and industry, as well as in households. Due to the uneven distribution of rainfall over time (annually, half occurs in winter, outside the agricultural season) and space (annual rainfall ranges from $50 \mathrm{~mm}$ in desert areas to $2000 \mathrm{~mm}$ in mountainous areas and along the Caspian Sea coast), groundwater constitutes the main resource of water in many regions of the country (Food and Agriculture Organization, 2009a: 3). However, 70 percent of groundwater potential has already been used (Laylin, 2018: 9). Out of 609 aquifers, 309 are overexploited, which has led to a ban on their use (Iran's, 2018). Although water is a renewable resource, this does not mean that it is inexhaustible. Excessive exploitation of aquifers reduces the level of groundwater until it is completely depleted.

The purpose of this article is to analyze Iran's hydrological security, defined as "the capacity of a population to safeguard sustainable access to adequate quantities of acceptable quality water for sustaining socio-economic development, for ensuring protection against water-borne pollution and water-related disasters, and for preserving ecosystems in a climate of peace and political stability" (United Nations University, Institute for Water, Environment and Health, 2013: 1). Hydrological security understood in this way encompasses the following dimensions:

1) physical access to water;

2) the use of clean, safe drinking water;

3) sustainable management of water resources that does not lead to their anthropogenic degradation, and prevents or reduces the risk of natural disasters such as floods and droughts. In addition, all elements of hydrological security should be achieved by and between local or regional communities and states, without using force. The article also attempts to evaluate the solutions implemented by Iranian decision makers at the government level that are to contribute to a more sustainable use of the country's valuable water resources.

The main hypothesis of the article is that the low level of Iran's hydrological security is one of the country's most important ecological threats. In order to verify the hypothesis, the following research questions were asked: firstly, what water resources does Iran have, and are citizens suffering from a shortage of water? Secondly, is the management of groundwater, closed reservoirs and rivers sustainable? Thirdly, do the actions of the Iranian authorities safeguard the hydrological security of the state? An attempt to answer these questions is made using the quantitative method, decisionmaking method and an institutional and legal analysis. 


\section{IRAN'S WATER RESOURCES - ANALYSIS OF THE PHYSICAL ACCESS TO ACCEPTABLE QUALITY WATER}

As a result of dynamic socio-economic development, the population of Iran increased from 17.1 million in 1950 to 34.8 million in 1977, which means the population doubled in just 27 years. It took another 28 years to double the population again - in 2005, there were 70.4 million Iranians. Population growth has been slowing since the 1990s. Currently, Iran's population is around 82 million, and according to forecasts by the United Nations Population Division, it will reach a peak in the mid-21st century (United Nations Population Division, 2017). As a consequence of the rapid growth of the country's population, Iran's water resources per capita have been decreasing. Annual renewable water resources per person fell from $4,555 \mathrm{~m}^{3}$ in 1972 to $1,732 \mathrm{~m}^{3}$ in 2014 (Food and Agriculture Organization, AQUASTAT database).

According to the scale developed by hydrologist Professor Malin Falkenmark, when the amount of water per person per year falls below $1,667 \mathrm{~m}^{3}$ one can talk about water stress. If the amount of available water resources is below $1,000 \mathrm{~m}^{3}$, this means that the population is affected by water scarcity, and when it is below $500 \mathrm{~m}^{3}$ one deals with absolute scarcity (Chalecki, 2013: 28). Iran's hydrological situation is inevitably leading to water stress. In 2020, renewable resources per capita may amount to as little as 1,300 $\mathrm{m}^{3}$ (Alizadeh, Keshavarz, 2005: 96). Experts estimate that the situation will continue to deteriorate until 2025, when Iranians will be affected by water scarcity and less than $1,000 \mathrm{~m}^{3}$ will be available per person (Iran, 2018a). Another indicator used to assess physical access to water is the rate of the total actual renewable water resources (TARWR) to demand. Water stress and severe water stress occur when the annual consumption of fresh water exceeds, respectively, 20 and 40 percent of renewable resources from this period (Mason, Calow, 2012: 22). In 2004, 67 percent of annual renewable resources were used in Iran, followed by 80 percent used in 2014 (The World Bank, online database, Level of water stress indicator).

In Iran, most water is used in agriculture and animal husbandry, although this sector generates only 9.5 percent of GDP (The World Bank, online database, Agriculture as a percent of GDP), and employs 18 percent of the population (Food and Agriculture Organization, 2018: 132). In 2004, Iranians used 92.2 percent of water in agriculture and farming, 6.6 percent in the municipal sector, and only 1.2 percent in industry (Food and Agriculture, Organization, 2009b: 190). Iran is in a group of 20 countries with the highest water use in agribusiness. Apart from Iran, only 13 countries (including Pakistan, Eritrea, Mali, Nepal and Sudan) used more water in the agricultural sector in 2006-2016 (Food and Agriculture Organization, 2018: 38).

The total area of the country is 165 million ha, of which 51 million ha are considered potentially arable land (The World Bank, 2004: 6). In 2016, land for plant, horticultural and animal production accounted for 46 million ha (28 percent of Iran's area), of which 14.7 million ha were arable land (including 12.3 million ha of grain), 1.8 million ha were orchards and permanent plantations of e.g. olives and pistachios, and 29.5 million ha were permanent grassland (such as pastures 
and meadows). In 2016, the irrigation system covered about 7.6 million ha (16.6 percent) of arable land (Food and Agriculture Organization Corporate Statistical Database). The country's irrigation potential, taking into account optimal conditions for water storage and use, is estimated at 15 million ha (Food and Agriculture Organization, 2009b: 191). Average irrigation efficiency ${ }^{1}$ in Iran was only 35 percent in 2008, however, thanks to the introduction of modern irrigation systems, it increased to 45 percent in 2018 (Iran Irrigation, 2018), which is less than the world average of 75 percent (Water, 2017).

The main reason for the high water consumption in the agricultural sector is the policy of food self-sufficiency, initiated after the Islamic revolution and consolidated during the Iran-Iraq war, during which food imports were significantly impeded. Decreasing oil exports and the resulting shortage of foreign currency, impaired food imports. Given the potential threat of an embargo on food exports to Iran, the dependence on imported agricultural products has become the country's strategic weakness. Iran's supreme leader Ruhollah Khomeini declared autarky in food products as a political priority. The revolutionary government deemed domestic agricultural production, which was the foundation for food security, a key sector of the economy (Woertz, 2013: 100). Currently, it covers about 90 percent of Iran's demand for food (Mesgaran, Madani, 2016: 5), compared to 35 percent in 1979 (Nabavi, 2018). Every year, Iran's first Vice President, Minister of Agriculture and Minister of Trade set a minimum guaranteed price for some strategic products, such as wheat, barley, cotton, sugar beet, corn, potatoes, onion and lentils. Immediately after the revolution, a 50 percent increase in wheat prices was established by the authorities, which have been raised many times since. In addition, the Iranian government guarantees the purchase of this grain (Dehnavi, 2015: 70, 72).

Cereals occupy 80 percent of Iran's arable land (Mesgaran, Madani, 2016: 5). Due to strong state support for wheat production, it accounts for nearly 70 percent of all cereals grown in Iran, while barley, corn and rice account for the remaining 30 percent. Wheat requires the most intensive irrigation - the world average is $1,8281 / \mathrm{kg}$. For rice, it is $1,6731 / \mathrm{kg}$. Less water is used to grow barley - an average of $1,4201 / \mathrm{kg}$ and maize - 1,222 1/kg (Mekonnen, Hoekstra, 2011: 1594). One-third of the wheat fields are irrigated. In the west and northeast, the harvest depends mainly on rainfall (Food and Agriculture Organization Global Information and Early Warning System, 2018).

In order to produce more food, a subsidy system has been introduced. Subsidies include purchase of fertilizers, pesticides, herbicides and seeds, among other things. Farmers can also take out loans at interest rates that are lower than commercial ones (The World Bank, 2004: 19-20). With regard to hydrological security, subsidizing the price of water for irrigation is important. In Iran, according to the provisions of the 1968 Law on the Nationalization of Water Resources, both surface water and groundwater are public property. The Ministry of Energy is responsible for water, and issues permits for drawing water for agricultural, industrial and domestic purposes, protects

${ }^{1}$ Irrigation efficiency is understood as the ratio of the volume of water used by plants to the volume of water supplied by the irrigation system (surface, rainfall or drip system). Definition after: Machibya, Mdemu, Lankford, 2004: II. 
water resources and controls their consumption, alongside the Ministry of Agriculture, responsible for water distribution for agricultural production as well as collection of fees, among other things. The distribution of water for domestic purposes, both in urban and rural areas, is carried out by private companies in individual provinces. The price of surface water and underground water for agricultural production has been set at a level below the costs of its supply, between 1-3 percent and between $0.25-1$ percent of the value of crops, respectively. If a well is located on private land, its owner does not pay for water used (Alasti, 2013 and Food and Agriculture Organization, 2009b: 195-196). Electricity and fuel prices are also subsidized, thanks to which rural residents pay less than 2 percent of the price for energy necessary for pumping water for irrigation purposes (Food and Agriculture Organization, 2009a: 10). The above subsidies do not encourage economical management of water resources, and can even result in their waste. Analyses from 1990-2015 indicate that the increase in agricultural productivity in Iran concerns vegetables and fodder crops rather than cereals, whose yield per hectare has been remaining at a similar level for years (Mesgaran, Madani, 2016: 5). The increase in production is associated with the increase in the cultivation area of crops.

In Iran, out of $93.3 \mathrm{~km}^{3}$ of water consumed, 56.9 percent came from aquifers, 42.9 percent from surface water, and 0.2 percent from desalination in 2004 (Food and Agriculture Organization, 2008: 190). The extraction of groundwater, on which agricultural production primarily depends, is currently carried out using cost-effective wells equipped with electric pumps, allowing water to be drawn from aquifers lying as deep as $300 \mathrm{~m}$. With the spread of Western solutions, the use of traditional irrigation systems - qanats, known in Iran for about 2,500 years, has decreased. Over fifty years, out of approximately 72,000 qanats only half have remained in use, currently supplying 14 percent of the water for agriculture (Bozorgmehr, 2014).

Qanats are vertical shafts, hollowed out in mountain slopes, connected by a gently descending tunnel. At the foot of the mountains the tunnel opens into a channel that carries the accumulated water to the farmland. This system guaranteed the sustainable management of water resources, using solely gravity to obtain them (Falkowski, Kostrowicki, 2005: 199). The possibility to easily and quickly reach for deep underground water resources has led to the spread of wells. Between the 1970s and 2000, groundwater extraction increased fourfold and the number of wells quintupled (Bozorgmehr, 2014). According to Iran's Ministry of Environment, 430,000 out of 780,000 wells were built illegally (Iran's renewable, 2018).

Domestic water consumption is high, at a level of 2501 per person per day, which is twice the global average. Urban areas are characterized by high use of water - e.g. the average in Tehran is 400 liters per person per day (Madani, AghaKouchak, 2016: 999). Water is not a valued good, first of all because of the very low municipal tariffs for water supply and sewage disposal. The tariffs are among the lowest in the Middle East and North Africa, as well as in many capitals of the world, as shown in Figure 1.

In Iran, 94.9 percent of the population have access to clean tap water, but its quality can become a serious challenge due to the seepage of agricultural, industrial and 
Figure 1. Combined water and wastewater bill per cubic meter, selected cities (USD, 2016)

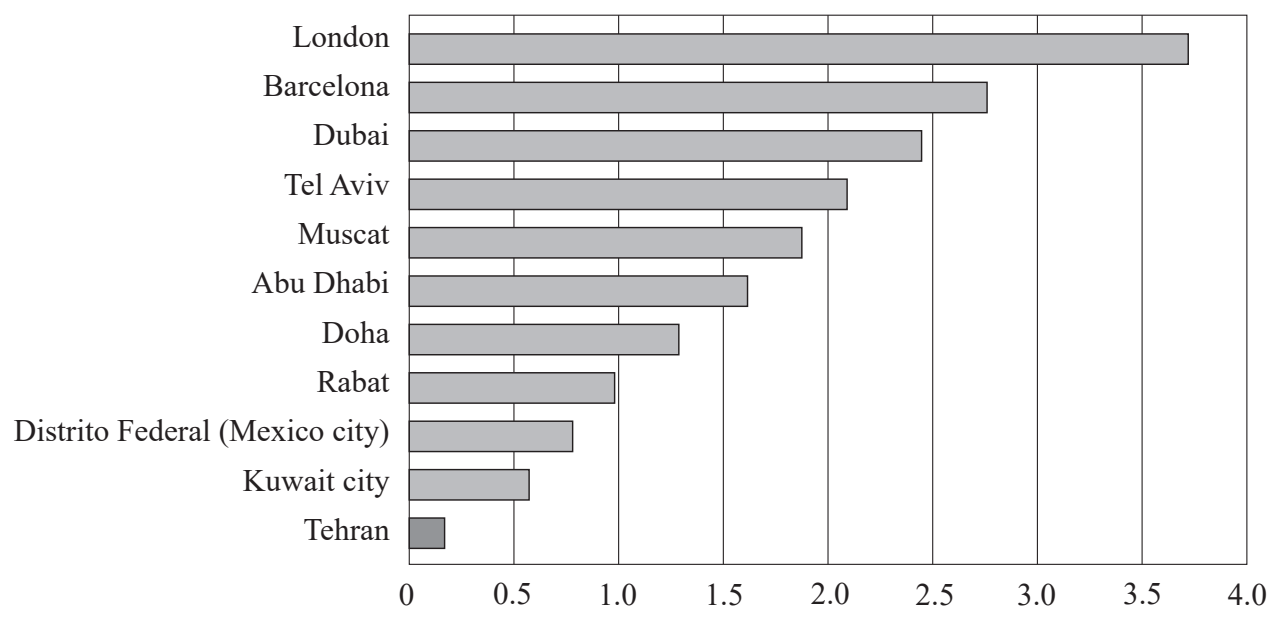

Source: World Bank Group (2017), Iran Economic Monitor. Oil-Driven Recovery, p. 40.

domestic pollution into surface water and groundwater (United Nations Development Programme, Human Development Indicators). Less than half of urban households are connected to the sewage network, and only 25 percent of wastewater in this network is treated; the remaining 75 percent is returned to the environment without treatment (World Bank Group, 2017: 40). Iran is one of five countries (next to China, India, Mexico and Pakistan) with the largest use of domestic wastewater in fields located within a $40 \mathrm{~km}$ radius of urbanized areas with a population of over 50,000 (Thebo, 2017: 6-7). Untreated water contains pathogens that can be a source of infectious diseases, e.g. cholera. In June 2018, 210 farmers from Abolfars, a village in Khuzestan, southwestern Iran, got poisoned most likely by consuming contaminated water (Islamic Republic News Agency, 2018a). Water pollution comes largely from agricultural activities; for instance, excessive use of mineral fertilizers leads to nitrogen and phosphorus seeping into groundwater, and fertilizers and pesticides get into rivers and lakes through surface runoff (Mateo-Sagasta, 2017: 11-13). On the other hand, when the water from aquifers and closed reservoirs is pumped excessively, their salinity increases.

\section{MANAGEMENT OF IRAN'S WATER RESOURCES}

The sustainable management of Iran's water resources is facing the challenge of the dynamic urbanization of the country, which is forecasted to increase by 1.71 percent per year in 2015-2020 (Central Intelligence Agency, The World Factbook). Young people decide to move, hoping for better living conditions in cities. Sometimes, leaving a farm is a necessity for the entire family due to the depletion of water resources, and the resulting loss of income from agricultural production. This is the situation, among others, of pistachio farmers from the province of Kerman, located in south- 
eastern Iran, one of the largest pistachio suppliers in the world. Over 15 percent of the approximately 61,000 ha with pistachio trees grown in the region have withered within ten years. In June 2015, 541 villages in this province depended on water supplies delivered by water carts (Erdbrink, 2015).

In 2018, nearly 75 percent of Iranians lived in urban areas, compared to a mere 27.5 percent in 1950, and 50.4 percent in 1981 (United Nations Population Division, 2018). The populations of eight Iranian cities exceed 1 million each, and over 100,000 people live in a further 76 cities. Over 14 million people live in Tehran, whose concentration on a small area is a significant burden on the hydrological system (Madani, 2014: 319). Cities are also characterized by outdated water distribution networks, whose maintenance and repair are not a priority for municipal authorities due to high costs. Water losses during transport with waterworks range from 15 to as much as 50 percent (World Bank Group, 2018: 214).

Over 600 dams were built after the Islamic revolution, compared to as few as 13 before 1979. Many hydro-technical constructions have been built by Khatam al-Anbiya, one of the largest contractors for industrial and development projects in Iran. The company is controlled by the Islamic Revolutionary Guard Corps. Khatam al-Anbiya's water projects provide plenty of water to large-scale landowners with significant influence in the provinces and to favored ethnic groups, while not taking into account the sustainable management of resources (Siegel, 2017). In order to secure support from rural communities, Iranian governments ensured that their demands for water were satisfied, allowing groundwater to be used without limit for years. One of the consequences involves land collapse in half of the Iranian plains along the Black Sea coast, the Persian Gulf and Oman Gulf (World Bank Group, 2018: 214).

As a result of the implementation of inland hydro-technical projects aiming to provide water to increasingly populated cities and to the fields, many closed reservoirs and rivers are drying up, for instance, the lakes of Urmia and Bakhtegan, the two largest lakes in Iran in the 1990s, and the Karoon River. Lake Urmia is located in the northwestern part of the country, close to the border with Turkey, between the provinces of West Azerbaijan and East Azerbaijan. In 2014, the area of the reservoir was 88 percent smaller than in 1972, while the volume of water was 20 percent of that in 1972. The water inflow from sixty rivers supplying the lake, including thirty-nine periodic ones, was restricted by building water dams (in 2014 there were 56 of them), primarily for irrigation projects (AghaKouchak, et al., 2014: 307-308; Dams to Blame, 2014). For example, in 1999, an installation was opened for the transfer of approximately 3 million $\mathrm{m}^{3}$ of water per year from the Zarrineh River to Tabriz, the largest city in East Azerbaijan. Water is used in households, industry and large-area fields surrounding the city (Khalyani, Mayer, Norman, 2014: 763). A long-term drought has also had an impact on the lake drying out. The demand for water in the region has increased significantly. In 1984-2014, the area of irrigated fields increased by 205,000 ha (from 304,000 to 509,000 ), while the urbanized area tripled from 17,400 ha to 56,000 ha. Ninety-one percent of the water that no longer supplies the lake is used in agriculture, while 6 and 3 percent is used in industry and individual households respectively (Zarrineh, Abad, 2014: 41). 
The salt lake Bakhtegan, located in the province of Fars in southern Iran, has dried up in less than two decades for the same reasons as Lake Urmia, namely due to a decreased amount of water supplying the lake (mainly from the Kor River) due to the increased demand for water from agriculture, the construction of dams (e.g. Mollasadra and Sivand) and drought (Bagheri, Bagheri, Sohooli, 2016: 1; Lake Bakhtegan, 2017). The water flow of many rivers in Iran has shrunk, including the largest of them - the Karoon, flowing from the Zagros Mountains in the state of Khahar Mahal and Bakhtiari (Central-West Iran) and then through the state of Khuzestan (South-West Iran), for which the river is the main source of water. The Karoon is a tributary of the Shatt al-Arab River which flows into the Persian Gulf (Encyclopaedia Iranica). During the Shah's rule, the first of several pipelines transporting water from the river was built to meet the needs of the residents of the capital of Isfahan and of local farmers, by feeding the Zayandeh-Rood River, which had been drying out. In the following years, the Karoon's waters were directed to other cities, including Qom, Yazd and Kerman (How Iran's, 2015). Twenty-four dams had been built on the river by 2014 (Dams to Blame, 2014). As a consequence, the river no longer reaches the capital of Khuzestan - Ahvaz.

Both farmers and residents of urban areas are voicing their dissatisfaction with the poor management of water resources. On June 30, 2018, riots and fights against the police broke out in the town of Khorramshahr (province/ostan of Kuzestan) following several weeks without access to clean water. The water supplied through pipelines from the Bahmanshir, Arvand and Karoon rivers was not drinkable, due to its salinity, which was as high as in sea water. The residents were supplied by water carts, which proved insufficient. As a consequence, the prices for bottled water increased. On June 28 , it was announced that the water from the municipal network could not be used for cooking and laundry, which triggered an outbreak of protests in which eleven people were injured (Authorities Admit, 2018).

Protests were also staged in the cities of Abadan and Mahshahr, located 20 and $110 \mathrm{~km}$ from Khorramshahr, respectively. In Abadan, the population could not use water in households for several weeks due to its salinity (the main source of intake is the Bahmanshir River), while Mahshahr demonstrated its support for residents of the province struggling with water shortages. The residents sought the reasons for the poor quality of water in the alleged sale of water resources from the Karoon River to Kuwait. Social media spread the information about a 30 -year contract having been signed between the two countries. Iran's Minister of Energy denied there were water exports (Iran Rejects, 2018). Social dissatisfaction was relieved neither by President Hassan Rouhani's assurance that funds had been allocated in the state budget for assistance in crises related to the lack of water (Center for Human Rights in Iran, 2018a) nor by declarations of the first Vice President Es'haq Jahangiri on the government's determination to restore regular supplies of water in Korramshahr and Abadan as soon as possible (Major Project, 2018).

Declining groundwater levels and rivers drying out are the outcome of a decadelong drought, the consequences of which are further aggravated by a lack of sustainable management of available resources (Salinity of, 2018b; Protesters, Police, 2018). The authorities believe that high salinity is caused by the excessive extraction of wa- 
ters by farmers and the rising level of water in the Persian Gulf, which breaks over into water-bearing areas. Shortages of potable water in Khorramshahr and Abadan are also associated with a run-down water supply infrastructure (Urban drought, 2018). The problem should be solved by the second and third lines of the Ghadir distribution network, which will facilitate the transfer of water over a distance of over $300 \mathrm{~km}$ from the dam on the Karkheh River to Khorramshahr and Abadan, and from the dam on the River Dez to Abadan. The Ghadir II system, financed from the central budget, was launched in the presence of the Minister of Energy Reza Ardakanian on June 4, 2018 (Major Project, 2018), and Ghadir III is scheduled to become operational in 2021 (Islamic Republic News Agency, 2018b ). The Ghadir Project is expected to meet 70 percent of water demand in Khorramshahr and 60 percent of that in Abadan (Water Shortage, 2018).

The increasing demand for water in cities leads to competition for water resources with residents of rural areas. In 2013, in the face of a prolonged drought, farmers from Isfahan (central Iran, Isfahan province) damaged the pump that sent the water from the Zayandeh-Rud River over a distance of about $300 \mathrm{~km}$ to the city of Yazd (Yazd province, one of the driest regions of Iran). As a result of a weekly protest, during which the farmers blocked access to the inoperative pump and clashed with the police, water was rationed in Yazd (Michel, 2013). The transport of water between Isfahan province and Yazd was initiated over 20 years ago by the then president of the state, Mohammad Khatami. According to an Iranian water resource management expert, who spoke anonymously to a French television station, this was "a gift [from the president - ASB] for Yazd, the city where he had been born" (France24, 2013).

The conflict over water in the region remains unsolved. Between March 2017 and November 2018, Isfahan's hydro-technical infrastructure was destroyed 24 times by farmers, who called on the government to take action to enable them to till the land. The authorities have answered by launching work on the third Koohrang tunnel. It will transport water from the mountain areas west and south-west of Isfahan to the drier regions east of the province. Residents of the neighboring provinces of Chahar Mahal and Bakhtiari, from whose mountains the Zayandeh-Rud River flows, have repeatedly protested against the transfer of their water to Isfahan (Angry Farmers, 2018).

Another example of competition for water resources was the protests by farmers in Kazeroon (Fars province) against disconnecting the pumps that irrigate their fields from the Shapour River in July 2018. According to officials, agricultural practices cause water shortages in the city of Borazjan, in the neighboring province of Bushehr. During the protests, a farmer from the village of Jahadabad died after being shot with a pellet gun, and two others were seriously injured (Center for Human Rights in Iran, 2018b).

The lack of sustainable resource management is demonstrated by the low efficiency of water use in the national economy (total water productivity). Among the countries of the Middle East and North Africa region (excluding Yemen and Syria), Iran has the smallest production volume and, consequently, the lowest income in relation to the volume of water used (e.g. cubic meter), as illustrated in Figure 2. 
Figure 2. Total water productivity in selected countries and economies (USD/m $\left.\mathbf{m}^{3}\right)$

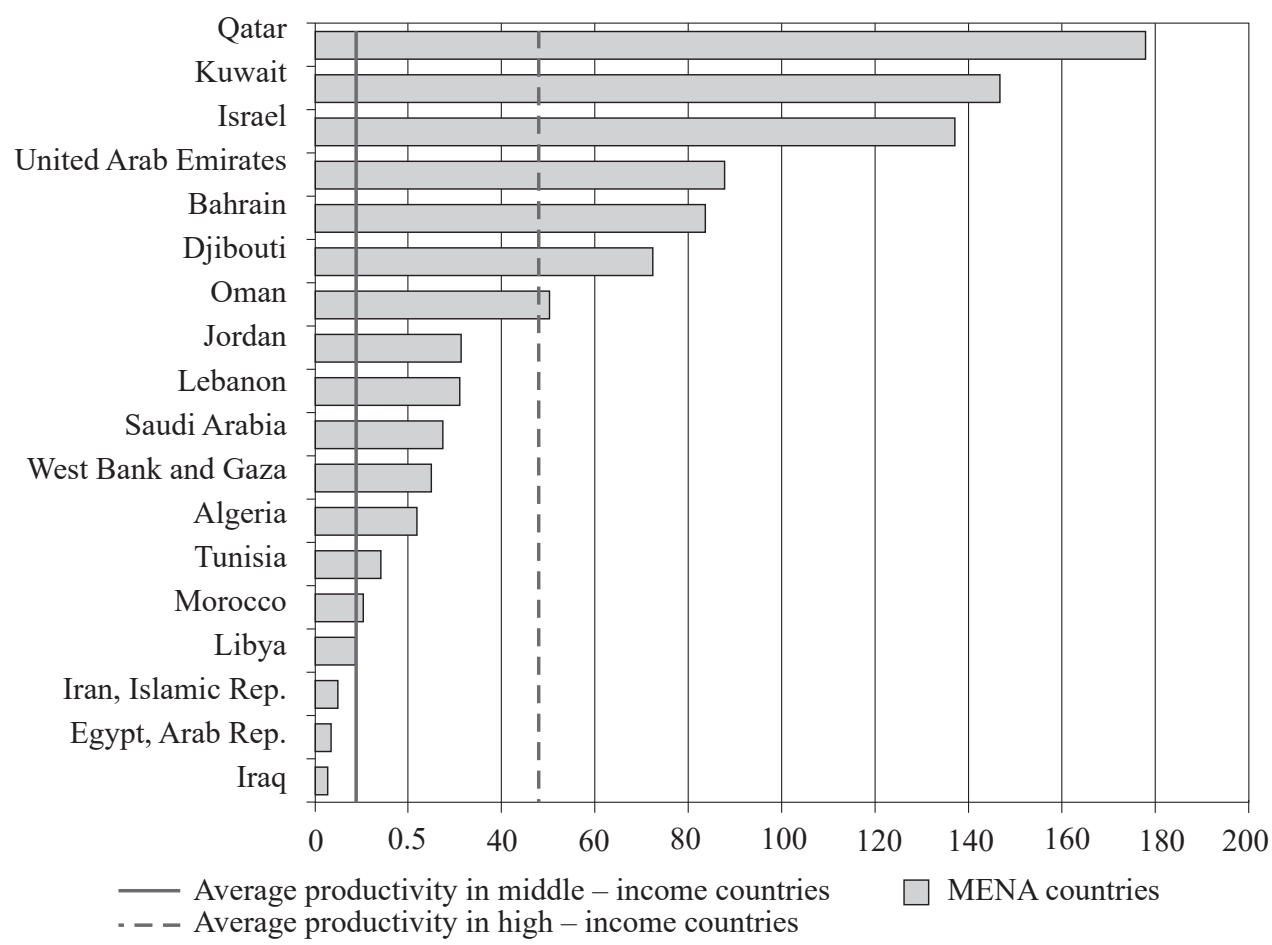

Source: World Bank Group (2018), Beyond Scarcity. Water Security in the Middle East and North Africa, Washington, p. 52.

\section{ACTIONS TO INCREASE IRAN'S HYDROLOGICAL SECURITY}

To ensure hydrological security to Iran, it is imperative to drastically limit the use of water in agriculture, which is associated with a shift from flood irrigation performed most often during the day, when evaporation is the greatest, and with the need to adapt food production to local climate conditions and existing water resources. In the opinion of the former Iranian Minister of Agriculture Issa Kalantari, maintaining water consumption in rural areas at the current level will result in the desertification of the eastern and southern parts of Iran in less than 25 years, and 50 million people will be forced to leave their homes (Kalantari: Water, 2016). The implementation of more efficient irrigation systems over the next decade and the change of agricultural production to less water-intensive crops (especially reducing wheat cultivation) may cost as much as $\$ 100$ billion (Bozorgmehr, 2014).

In 2014, the Iranian Supreme Water Council ${ }^{2}$ adopted a plan providing, among other things, for the protection and renewal of groundwater by detecting and regulating

${ }^{2}$ The Iranian Supreme Water Council coordinates the work of the Ministry with respect to the management of the country's water resources. The Council is headed by the President of Iran (Ardakanian, 2005: 24). 
excessive pumping. The following activities have been identified: installing meters in wells, equipping auger drills for drilling deep wells with GPS devices, and establishing groups that control the level of water use. Regardless of the methods used, Iranians resisting reductions on the consumption of water that they have been using abundantly for years may be an obstacle. This is evidenced by the statements by farmers from the Fars province, such as: "even if the authorities responsible for water management install groundwater consumption meters, people will not resist; they will find a way to collect water bypassing them instead" (Nabavi, 2018).

More rational water management in urban areas is also imperative. In April 2018, water shortages occurred in 334 cities inhabited by a total of 35 million people, as noted by the Minister of Energy in his speech to the administration of President Hassan Rouhani (Angry Farmers, 2018). Setting appropriate water tariffs, consumption restrictions imposed under certain conditions (e.g. prolonged drought) in specific sectors of the economy, and for specific activities at the level of individual users (e.g. watering gardens), and penalties imposed for non-compliance with prohibitions, may be tools to reduce the demand. Funds obtained in this way should support, among other things, the protection of underground resources and maintenance of the water supply network. In accordance with the sixth five-year plan for economic, social and cultural development in 2016-2021, the Executive has been obliged by the parliament - the Islamic Consultative Assembly, to implement the necessary measures to reduce potable water consumption by 30 percent by March 2021 (Kordvani, Berenjforoush, 2017).

Iran's hydrological security may also be improved by solutions pertaining to supply, including investing in the desalination of sea water. The sixth plan for economic, social and cultural development envisages that the government will take action to provide at least 30 percent of drinking water in southern Iran from desalination in 2021. In December 2018, the largest water desalination plant in Iran, with a target production potential of $100,000 \mathrm{~m}^{3}$ of water per day, was opened in the city of Bandar Abbas, located on the Strait of Hormuz (Hormuz Province). It is a private sector investment of $\$ 204$ million. At the end of 2018, 85 water desalination plants were under construction, with a combined potential of $400,000 \mathrm{~m}^{3}$ per day (FARS News Agency, 2018). The transport of desalinated water from the Persian and Oman Gulfs to 47 million people is also being considered in 16 provinces in central Iran (MP Push, 2017).

The solutions to the problems of water shortage on the supply side also include collecting rainwater and increasing the level of recycling, i.e. the reuse of purified water, e.g. for industrial purposes, field irrigation, and the watering of urban greenery. Only 1.2 billion $\mathrm{m}^{3}$ of 4.3 billion $\mathrm{m}^{3}$ of wastewater is reused in Iran. In February 2018, on the occasion of the 39th anniversary of the Islamic Revolution, 100 wastewater treatment plants were opened throughout the country as part of public-private partnership (Iran Makes, 2018). Among the countries of the Middle East and North Africa, Iran, alongside Egypt and Syria, may benefit the most from the introduction of better solutions for water supply and storage in rural areas by increasing yields by up to 8 percent (World Bank Group, 2018: 38).

There is no doubt that solving the problem of shrinking water resources has been addressed by successive governments, but the actions taken so far should be considered insufficient, as they have focused primarily on satisfying growing demand. 
Hydro-technical installations used to transport water and reduce water stress in one place soon become the reason for shortages in the intake areas, as exemplified by the above-described tense situation along the Zayandeh-Rud River. Subsidizing water prices for agriculture, very low municipal tariffs for sewage disposal and water supplies ( $\$ 0.9$ per $^{3}$, compared to a cost of delivery of $\$ 0.21$ ) (Iran Makes, 2018), and little control by state authorities over the use of available resources, all lead to the inefficient use of water resources and even encourage Iranians to overexploit them.

In 2010, the law envisaging the increase of electricity and water tariffs entered into life, providing for the tariffs to cover the total costs of delivery over five years; for the gradual balancing out of energy prices with prices on the international market, and for the abolition of subsidies for wheat, rice, oil, milk and sugar until 2015 (Law for the Targeting of Subsidies, 2009). Ultimately, the subsidy system will be replaced by direct money transfers, the amount of which will depend on the income per person in the household. Due to inflation rising as an aftermath of the sanctions imposed on Iran, in 2012, the Islamic Consultative Assembly suspended the reform. In 2014 and 2015, the subsidies were reduced again, but the objectives set in the above law were not fully achieved (Michel, 2017: 173). According to the sixth five-year development plan, this is to take place in 2021 (Rouhani presents, 2016). If the Iranian authorities want to increase the level of hydrological security, the reform should be finally implemented, which can also be indicated by the awareness of the impact of water prices on the level of its consumption, which was emphasized by Minister of Energy Reza Ardakanian: "As long as water prices are not modified, neither can we tackle the water shortage nor will people and industries change their consumption patterns" (Iran Makes, 2018).

$$
* * *
$$

Iran is facing a serious ecological crisis due to a low level of hydrological security. This is related to the following factors that have been analyzed in the framework of the research questions (what water resources does Iran have, and are citizens suffering from a shortage of water; is the management of groundwater, closed reservoirs and rivers sustainable; and, do the actions of the Iranian authorities safeguard the hydrological security of the state?):

1) The demand for water in Iran is increasing, in agriculture, industry and households. In 2014, 80 percent of the annual renewable fresh water resources were used in Iran, which means that the state is under severe water stress, defined as the consumption of at least 40 percent of fresh water and its renewable resources. Water shortages affect both the inhabitants of rural and urban areas, triggering protests and local conflicts.

2) Groundwater, closed reservoirs and rivers are not managed in a sustainable way, as evidenced by the declining groundwater levels and the consequent land collapsing, drying out lakes (e.g. Urmia and Bakhtegan), rivers (e.g. Zayandeh-Rud and Karoon) and wetlands (e.g. Gavkhouni and Jazmourian).

3) The actions of the Iranian authorities are insufficient to safeguard long-term water resources for agriculture, households and industry. The policy of food self-sufficiency initiated after the Iranian revolution, analyzed in this article, is an example 
of state actions encouraging the unlimited use of water resources rather than promoting looking after this valuable resource.

\section{REFERENCES}

AghaKouchak et al. (2015), Aral Sea syndrome desiccates Lake Urmia: Call for action, "Journal of Great Lakes Research”, Vol. 41, Issue 1, https://doi.org/10.1016/j.jglr.2014.12.007.

Alasti S. (2013), Legislation on Use of Water in Agriculture: Iran, Library of Congress, https://www. loc.gov/law/help/water-law/iran.php\#_ftn30 (14.02.2019).

Alizadeh A., Keshavarz A. (2005), Status of Agricultural Water Use, in: Iran, Water Conservation, Reuse and Recycling: Proceedings of an Iranian-American Workshop, Washington.

Angry Farmers In Isfahan Sabotage Supply To Neighbouring Yazd (2018), Radio Farda, 25.11.2018, https://en.radiofarda.com/a/iran-isfahan-farmers-sabotage-water-transfer-system-toyazd/29620054.html (4.03.2019).

Ardakanian R. (2005), Overview of Water Management in Iran, in: Water Conservation, Reuse, and Recycling: Proceedings of an Iranian-American Workshop, Washington.

Authorities Admit At Least 11 Injured In Protests Over Lack Of Water (2018), Radio Farda, https:// en.radiofarda.com/a/khorramshahr-water-protests-turn-violent-/29330047.html (2.03.2019).

Bagheri M., Bagheri A., Sohooli G. (2016), Analysis of Changes in the Bakhtegan Lake Water Body under the Influence of Natural and Human Factors, "Iran - Water Resources Research", Vol. 12, No. 3.

Bozorgmehr N. (2014), Iran: Dried out, "Financial Times", 21.08.2014, https://www.ft.com/ content/5a5579c6-0205-11e4-ab5b-00144feab7de (15.02.2019).

Center for Human Rights in Iran (2018a), Shots Fired at Protest as Officials Unable to Ease Water Shortage Crisis in Iran's Khuzestan Province, https://iranhumanrights.org/2018/07/shotsfired-at-protest-as-officials-unable-to-ease-water-shortage-crisis-in-irans-khuzestan-province/ (1.03.2019).

Center for Human Rights in Iran (2018b), Local Police in Iran Admit Killing Farmer at Protest Against Water Shortages, 13.06.2018, https://iranhumanrights.org/2018/07/local-police-iniran-admit-killing-farmer-at-protest-against-water-shortages/ (7.03.2019).

Central Intelligence Agency, The World Factbook, online database, https://www.cia.gov/library/publications/resources/the-world-factbook/geos/ir.html (22.02.2019).

Chalecky E. L. (2013), Environmental Security. A Guide to the Issues, Santa Barbara, Denver, Oxford.

Dams to Blame for Extreme Drought (2014), "Financial Tribune", 23.09.2014, https://financialtribune.com/articles/people/1140/dams-to-blame-for-extreme-drought (26.02.2019).

Dehnavi S. (2015), Water Resource Availability, National Food Security Strategies and Farmers ‘ Reactions in Darab, Iran, Kassel.

Encyclopaedia Iranica, Karun River, Geography and Hydrology, http://www.iranicaonline.org/articles/karun_1_2 (28.02.2019).

Erdbrink T. (2015), Scarred Riverbeds and Dead Pistachio Trees in a Parched Iran, "The New York Times", 18.12.2015.

Falkowski J., Kostrowicki J. (2005), Geografia rolnictwa świata, Warszawa.

FARS News Agency (2018), Iran to Open Largest Desalination Plant, 11.12.2018, http://en.farsnews. com/newstext.aspx?nn=13970920000336 (5.03.2019). 
Food and Agriculture Organization (2009a), Groundwater Management in Iran. Draft Synthesis Report, Rome.

Food and Agriculture Organization (2009b), Irrigation in the Middle East region in figures - AQUASTAT Survey 2008, (ed.) K. Frenken, Rome.

Food and Agriculture Organization (2018), World Food and Agriculture Statistical Pocketbook 2018, Rome.

Food and Agriculture Organization, AQUASTAT database, Total renewable water resources per capita, http://www.fao.org/nr/water/aquastat/data/query/results.html (6.02.2018).

Food and Agriculture Organization Corporate Statistical Database, FAOSTAT, http:/www.fao.org/ faostat/en/\#country/102 (8.02.2018).

Food and Agriculture Organization Global Information and Early Warning System (2018), Country Brief: Iran, http://www.fao.org/giews/countrybrief/country.jsp?lang=en\&code=IRN (11.02.2018).

France24 (2013), A tale of two Iranian cities, battling for water, 3.01.2013, https://observers.france24. com/en/20130228-iran-isfahan-yazd-farmers-water-protest-pump (3.03.2019).

How Iran's Khuzestan went from wetland to wasteland (2015), “The Guardian", 16.04.2015, https:// www.theguardian.com/world/iran-blog/2015/apr/16/iran-khuzestan-environment-wetlandsdust-pollution (28.02.2019).

Iran Irrigation Efficiency at 45 percent (2018), "Financial Tribune", 26.02.2018, https://financialtribune.com/articles/economy-business-and-markets/82603/iran-irrigation-efficiency-at-45 (8.02.2019).

Iran Makes Big Step Towards Long Term Water Conservation (2018), Active Water Solution, 8.01.2018, http://www.activewatersolutions.com/blog/iran-makes-big-step-towards-longterm-water-conservation (6.02.2019).

Iran Rejects Rumours of Exporting Water to Kuwait (2018), "Iran Front Page", 28.06.2018, https:// ifpnews.com/exclusive/iran-rejects-rumours-of-exporting-water-to-kuwait/ (1.03.2019).

Iran's renewable water resources decreased by 25 percent in 5 decades (2018), "Tehran Times", https://www.tehrantimes.com/news/425837/Iran-s-renewable-water-resources-decreasedby-25-in-5-decades (5.02.2019).

Islamic Republic News Agency (2018a), Number of poisoned villagers in south of Iran reaches 210, 1.06.2018, http://www.irna.ir/en/News/82958094 (18.02.2019).

Islamic Republic News Agency (2018b), Biggest water supply plan to be launched in southern Iran, 3.07.2018, http://www.irna.ir/en/News/82960605 (3.03.2019).

Kalantari: Water shortage more harmful than Iraq's war on Iran in 1980s (2016), "Tehran Times", 17.09.2016, https://www.tehrantimes.com/news/406486/Kalantari-Water-shortage-moreharmful-than-Iraq-s-war-on-Iran (22.02.2019).

Khalyani A., Mayer A., Norman E. (2014), Water Flows Toward Power: Socioecological Degradation of Lake Urmia, Iran, "Society and Natural Resources", Vol. 27, Issue 7, https://doi.org/ 10.1080/08941920.2014.905890.

Kordvani A., Berenjforoush P. (2017), Iran approves the Sixth Development Plan to boost investment, https://www.lexology.com/library/detail.aspx?g=9a25e9cc-44d0-45fa-9a54-905de434fc66 (4.03.2019).

Lake Bakhtegan turns into salt flat (2017), "Iran Daily", 24.10.2017, http://www.iran-daily.com/ News/203033.html (28.02.2019).

Law for the Targeting of Subsidies (2009), Iran Data Portal, http://irandataportal.syr.edu/full-text-ofthe-law-for-the-targeting-of-subsidies-december-2009 (11.03.2019). 
Laylin D. (2018), Environmental and Wildlife Degradation in Iran, Atlantic Council South Asia Center, Washington.

Machibya M., Mdemu M., Lankford B. (2004), Draft Irrigation Efficiency and Productivity Manual. Tools for Irrigation Professionals and Practitioners, Mbeya.

Madani N. (2014), Water management in Iran: what is causing the looming crisis?, "Society and Natural Resources: An International Journal”, Vol. 4, Issue 4, https://doi.org/10.1007/ s13412-014-0182-z.

Major Project Inaugurated to End Water Crisis in Southern Iran (2018), "Iran Front Page", 5.07.2018, https://ifpnews.com/exclusive/water-crisis-southern-iran/ (3.03.2019).

Mason N., Calow R. (2015), Water security: from abstract concept to meaningful metrics. An initial overview of options, Overseas Development Institute Working Paper 357, London.

Mateo-Sagasta J., Zadeh S., Turral H. (2017), Water pollution from agriculture: a global review. Executive summary, Rome, Colombo.

Mekonnen M., Hoekstra A. (2011), The green, blue and grey water footprint of crops and derived crop products, "Hydrology and Earth System Sciences", No. 15, https://doi.org/10.5194/ hess-15-1577-2011.

Mesgaran M., Madani K., Hashemi H., Azadi P. (2016), Evaluation of Land and Precipitation for Agriculture in Iran, Working Paper 2, Stanford Iran 2040 Project, Stanford University, https://purl.stanford.edu/vf990qz0340 (11.02.2019).

Michel D., Iran's Environment: Greater Threat than Foreign Foes, 28.10.2013, https://iranprimer. usip.org/blog/2013/oct/28/iran's-environment-greater-threat-foreign-foes (3.03.2019).

Michel D. (2017), Iran's Impending Water Crisis, in: Water, Security and U.S. Foreign Policy, (ed.) D. Reed, New York-London.

MP push for Desalination Project in Southern Iran (2017), "Iran Business News", 1.01.2017, http://www.iran-bn.com/2017/01/01/mp-push-for-desalination-project-in-southern-iran/ (4.03.2019).

Nabavi E. (2018), Failed Policies, Falling Aquifers: Unpacking Groundwater Overabstraction in Iran, "Water Alternatives", No. 11, Issue 3.

Protesters, Police Clash for Second Night in Southwest Iran (2018), Radio Farda, 2.06.2018, https:// www.rferl.org/a/protesters-police-clash-for-second-night-in-southwestern-iran/29333107. html (3.03.2019).

Rouhani presents $\$ 262 b$ budget bill to Majlis (2016), “Tehran Times", 18.01.2016, https://www. tehrantimes.com/news/252294/Rouhani-presents-262b-budget-bill-to-Majlis (11.03.2019).

Salinity of City Water Leads to Protests in Abadan (2018), Radio Farda, 24.06.2018, https:// en.radiofarda.com/a/iran-abadan-salty-water-protests/29316553.html (3.03.2019).

Siegel S., Forget the politics. Iran has bigger problems, "Washington Post", 16.05.2017, https:// www.washingtonpost.com/news/democracy-post/wp/2017/05/16/forget-the-politics-iranhas-bigger-problems/?utm_term=.dae55bceb0e6 (22.02.2019).

The World Bank, online database, Agriculture, forestry and fishing as per cent of GDP, https://data. worldbank.org/indicator/NV.AGR.TOTL.ZS (8.02.2019).

The World Bank, online database, Level of water stress: freshwater withdrawal as a proportion of available freshwater resources indicator, https://data.worldbank.org/indicator/ER.H2O. FWST.ZS?locations=IR (8.02.2019).

The World Bank (2004), Water, Environment, Social and Rural Development Department, Middle East and North Africa Region, Islamic Republic of Iran. An Agricultural Policy Note, Report No. 29428-IR. 
Thebo A., Drechsel P., Lambin E., Nelson K. (2017), A global, spatially-explicit assessment of irrigated croplands influenced by urban wastewater flows, "Environmental Research Letters", No. 12, https://doi.org/10.1088/1748-9326/aa75d1.

United Nations Development Programme, Human Development Indicators, http://hdr.undp.org/en/ countries/profiles/IRN (19.02.2019).

United Nations Population Division (2017), World Population Prospects 2017, Population online database, https://population.un.org/wpp/DataQuery/ (6.02.2019).

United Nations Population Division (2018), World Urbanization Prospects 2018, https://population. un.org/wup/Country-Profiles/ (22.02.2019).

United Nations University, Institute for Water, Environment and Health (2013), Water Security \& the Global Water Agenda, Hamilton.

Urban drought forces Iran to seek resolution, "The Source" - magazine of the International Water Association, 9.07.2018, https://www.thesourcemagazine.org/urban-drought-forces-iran-toseek-resolution/ (3.03.2019).

Water Consumption Near Full Capacity (2017), "Financial Tribune”, https://financialtribune.com/ articles/environment/57556/water-consumption-near-full-capacity (8.02.2019).

Water Shortage in Southern Iran Turns into Crisis (2018), "Iran Front Page”, 1.06.2018, https://ifpnews.com/exclusive/water-shortage-in-southern-iran-turns-into-crisis/ (3.03.2019).

World Bank Group (2017), Iran Economic Monitor. Oil-Driven Recovery, Washington.

World Bank Group (2018), MENA Development Report. Beyond Scarcity. Water Security in the Middle East and North Africa, Washington.

Woertz E. (2013), Oil for Food. The Global Food Crisis and the Middle East, Oxford.

Zarrineh N.,Abad M. (2014), Integrated water resources management in Iran: Environmental, socio-economic and political review of drought in Lake Urmia, "International Journal of Water Resources and Environmental Engineering”, Vol. 6 (1), https://doi.org/10.5897/IJWREE2012.0380.sc.

\begin{abstract}
The main objective of this paper is to analyze Iran's hydrological security and to verify the hypothesis that the low level of Iran's hydrological security is one of the country's most important ecological threats. An attempt to answer the following research questions is made using the quantitative method, decision-making method and institutional and legal analysis: (1) what water resources does Iran have, and are citizens suffering from a shortage of water?; (2) is the management of groundwater, closed reservoirs and rivers sustainable?; (3) do the actions of the Iranian authorities safeguard the hydrological security of the state? The analysis of the factors of Iran's water security carried out in this paper leads to the conclusion that this country is facing a serious ecological crisis resulting from shrinking fresh water resources.
\end{abstract}

Keywords: Iran, hydrological security, water security, water stress, water shortages, ecological security

\title{
BEZPIECZEŃSTWO HYDROLOGICZNE IRANU - WYBRANE ASPEKTY
}

\section{STRESZCZENIE}

Celem artykułu jest analiza bezpieczeństwa hydrologicznego Iranu i weryfikacja następującej hipotezy: niski poziom bezpieczeństwa hydrologicznego stanowi jedno z najważniejszych 
zagrożeń ekologicznych tego państwa. Przy wykorzystaniu metody ilościowej, decyzyjnej i analizy instytucjonalno-prawnej podjęto próbę odpowiedzi na następujące pytania badawcze: (1) jakimi zasobami wodnymi dysponuje Iran i czy obywateli dotykają niedobory tego surowca?; (2) czy zarządzanie wodami podziemnymi, zbiornikami zamkniętymi i rzekami odbywa się w sposób zrównoważony? (3) czy działania irańskich władz zapewniają bezpieczeństwo hydrologiczne państwa? Analizowane w artykule komponenty bezpieczeństwa wodnego Iranu prowadzą do wniosku, że państwo to stoi w obliczu poważnego kryzysu ekologicznego wynikającego z kurczących się zasobów wody słodkiej.

Słowa kluczowe: Iran, bezpieczeństwo hydrologiczne, bezpieczeństwo wodne, stres wodny, niedobory wody, bezpieczeństwo ekologiczne 